\title{
骨転移を伴った悪性黒色腫
}

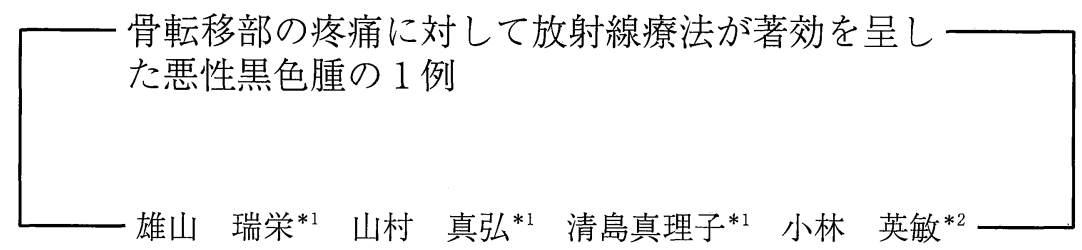

\section{Effective control for the pain by bone metastases of malignant melanoma by radiation therapy}

Zuiei OYAMA*1, Mahiro YAMAMURA *1, Mariko SEISHIMA*1, Hidetoshi KOBAYASHI *2

*1 Department of Dermatology, Ogaki Municipal Hospital

*2 Department of Radiology, Nagoya University School of Medicine

We report a case of malignant melanoma of a 44-year-old female. The patient developed a subcutaneous nodule on her scalp during the past 3 months. It was diagnosed as maligmant melanoma by biopsy of the subcutaneous nodule, and she was treated with combination chemotherapy with dacarbazine (DTIC), ACNU, vincristine (VCR) and interferon(IFN) $\beta$ after the operative excision of the nodule with a $3 \mathrm{~cm}$ margin around the lesion. After 3 years, lung metastasis was found and combination chemotherapy with DTIC, ACNU, cisplatin (CDDP) and tamoxifen (TAM) and a combination of IFN $\alpha$ and DTIC were performed, but they were not effective. Recently, metastases to the left coxa, right tibia and right femur occurred and the bone metastases caused intolerable pain which necessitated the administration of morphine sulfate. Radiotherapy (70Gy, 60Gy and 35Gy) was performed for these bone metastases, respectively. The pain disappeared, although the sizes of the lesions did not change. [Skin Cancer (Japan) 2001 ; 16:314-318]

Key words : Malignant melanoma, Bone matastasis, Radiation therapy

\section{はじめに}

悪性腫瘍患者では骨転移を伴う場合，その疼 痛は患者の QOL (quality of life) に大きな影響を 及ぼす。今回我々は，悪性黒色腫の骨転移によ

*1 大垣市民病院皮膚科

$* 2$ 名古屋大学放射線科
る疼痛に対して放射線療法が著効を呈した 1 例 を経験したので，若干の文献的考察を加えて報 告する。

\section{症例}

患 者: 44 歳, 女性
主 訴: 頭部の皮下腫瘤
初 診: 1995 年 7 月 18 日 
家族歴・既往歴：特記すべきことなし

現病歴：1995年 4 月, 右側頭部の小豆大の皮 下結節に気づいた。同年 7 月に近医で切除した ところ, 病理組織所見より悪性黒色腫を疑われ 当科を紹介された。

初診時現症: 右側頭部の前医で切除術を行っ た手術創に血痂, 出血を伴った直径 $10 \mathrm{~mm}$ の小 潰瘍を認めた（図 1 )。

治療および経過：入院後, 病変部より $3 \mathrm{~cm}$ 離 して帽状腱膜直上まで桩大切除し, また右頸部 リンパ節郭清術も同時に施行した。拡大切除し た組織の H.E. 染色像では, 真皮から皮下脂肪織 にかけて腫瘍細胞が散在し, さらに皮下には直 径 $4 \mathrm{~mm}$ の腫瘍細胞塊を認めた（図 2 )。腫瘍細 胞塊はクロマチンに富む棈円形の核を持った紡 錘形の腫瘍細胞で構成され，また分裂像も散見

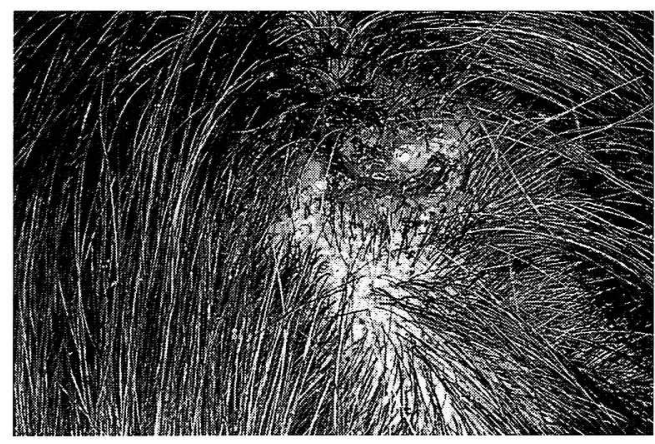

図 1. 初診時臨床像 右側頭部の小潰嗙

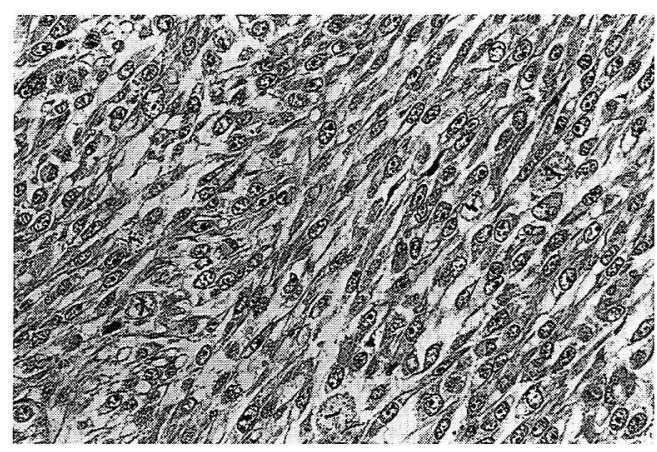

図 3. H.E. 染色強拡大像（皮下の腫湟細胞塊） クロマチンに富む異型細胞と分裂像がみられ る
された（図 3 )。これらの細胞は HMB-45 染色 陽性であった。なお，郭清したリンパ節に転移 は認めなかった。これらの所見より本症例を黄 性黒色腫 (Stage III $\left.\left(\mathrm{T}_{4} \mathrm{~N}_{0} \mathrm{M}_{0}\right)\right)$ と確定診断した。 術後, DAV-フェロン療法 ${ }^{1}$ ) (dacarbazine (DTIC) $140 \mathrm{mg} / \mathrm{m}^{2} \times 5$ days, ACNU $60 \mathrm{mg} / \mathrm{m}^{2} \times$ lday, vincristine (VCR) $0.6 \mathrm{mg} / \mathrm{m}^{2} \times 1$ day, interferon (IFN) $\beta 300$ 万単位 $\times 10$ days) を 5 クール施行した。

術後 2 年 9 カ月経過した 1998 年 5 月に胸部 CT で右下肺野に $15 \times 16 \mathrm{~mm}$ の腫瘤影を 1 個認 めた（図 4 )。経気管支肺生検の結果, 悪性黑色

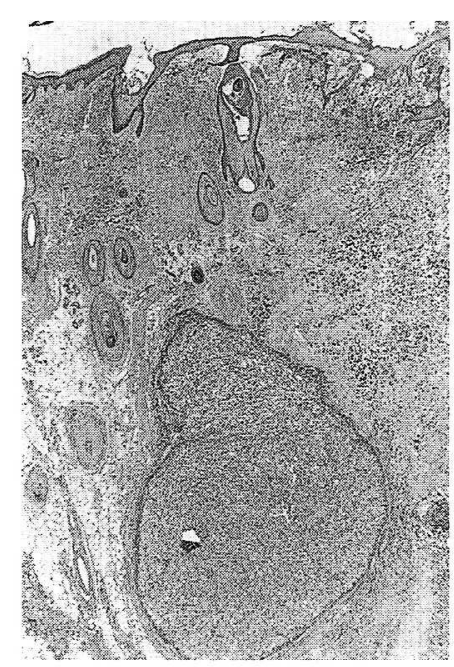

図 2. H.E. 染色弱拡大像 皮下に腫瘍細胞塊がみられる

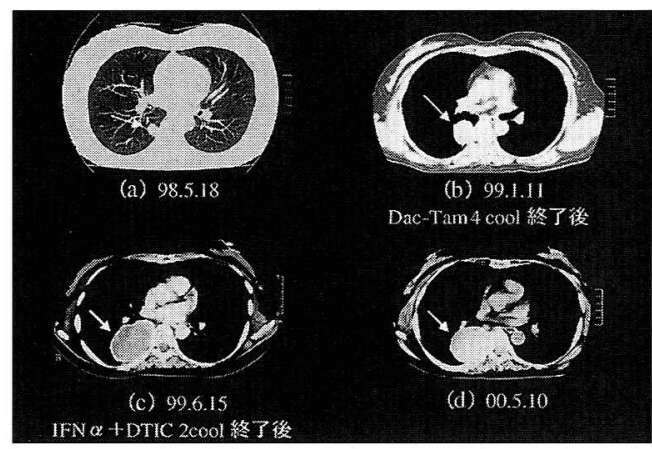

図 4. 胸部 $C T$ 像 右下肺野の腫瘤影は化学療法後も增大した 
腫の肺転移と診断されたため, DAC-Tam 療法 ${ }^{2)}$ (DTIC $220 \mathrm{mg} / \mathrm{m}^{2} \times 3$ days, ACNU $60 \mathrm{mg} / \mathrm{m}^{2} \times$ 1day, cisplatin (CDDP) $25 \mathrm{mg} / \mathrm{m}^{2} \times 3$ days, tamoxifen(TAM) $20 \mathrm{mg} /$ day 連日内服)を 4 クー ル施行した。しかし肺転移巣は拡大したため, 1999 年 4 月より IFN $\alpha+$ DTIC 療法 ${ }^{3) を ~} 2$ クー ル施行したが腫瘤はさらに増大した。また 1999 年 6 月には左胸部に常色母指頭大の皮下腫瘤が 出現した。摘出した皮下腫瘤は半割したところ 黒色調を呈しており，組織像でも悪性黒色腫の 皮下転移と診断された（図 5 )。

これまでの化学療法が無効であり，また副作 用としての骨髄抑制が強くみられたため以後は 経過観察のみとしていたが, 半年後の1999年12 月に左下腹部に疼痛が出現し，腹部骨盤腔 CT にて左寛骨に腫瘍の浸潤像を認めた（図 6 )。 2000 年 1 月より同部位に対し放射線療法を開 始し，10MVX 線 70Gy（2Gy/ 回，計 35 回）を 照射した。しかし， CT 上腫瘍は増大し疼痛も 変わらなかったため， 2000 年 2 月より硫酸乇

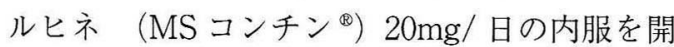
始し, 徐々に増量した。それに伴い, 本剤の副 作用と考えられる吐気，頭痛，便秘を訴えるよ うになった。その後, 右脛骨にも転移を認め (図 7 ) 疼痛を生じたため, 2000 年 7 月より 10MVX 線 60Gy (2Gy/ 回, 計 30 回) を照射したところ, 照射開始してから 2 週間後には右脛骨の疼痛は

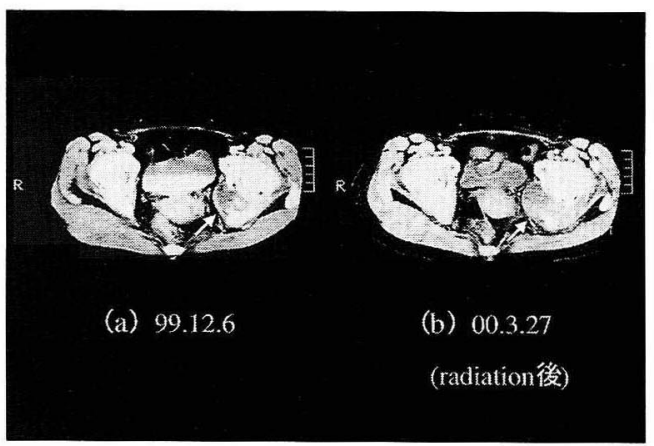

図6.骨盤腔 CT像 左寛骨の腫瘍塊は放射線療法後もやや増大し た
軽減し左下腹部の疼痛も軽快したため, 硫酸モ ルヒネを中止することができた。しかし，さら に右大腿骨にも転移し（図 7 ）疼痛を生じたた め硫酸モルヒネを再開したが，右大腿骨にも 2000 年 11 月に 10MVX 線 30Gy (6Gy/ 回, 計 5 回）を照射したところ, 再び疼痛は軽快し再度 硫酸モルヒネを中止した。なお，右脛骨抢よび 右大腿骨においても治療の前後で画像上，骨浸 潤像に変化はみられなかった。2001 年 7 月現在 も疼痛は非ステロイド系消炎鎮痛剂の坐薬のみ でコントロールできている。

\section{考 察}

本症例では悪性黒色腫の骨転移巣に放射線療

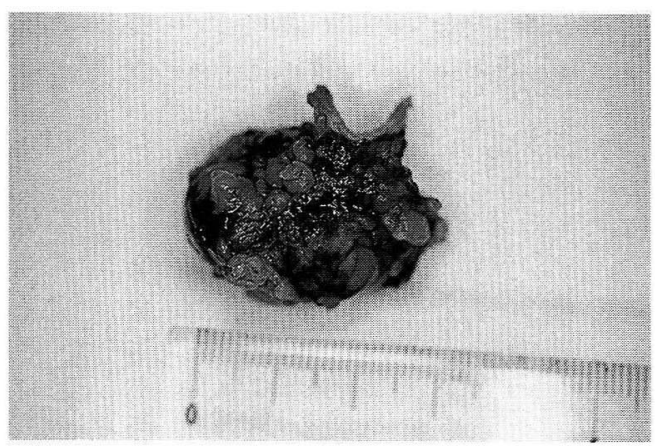

図 5. 左胸部に生じた皮下腫瘤 半割したところ黒色の摘出標本を呈した

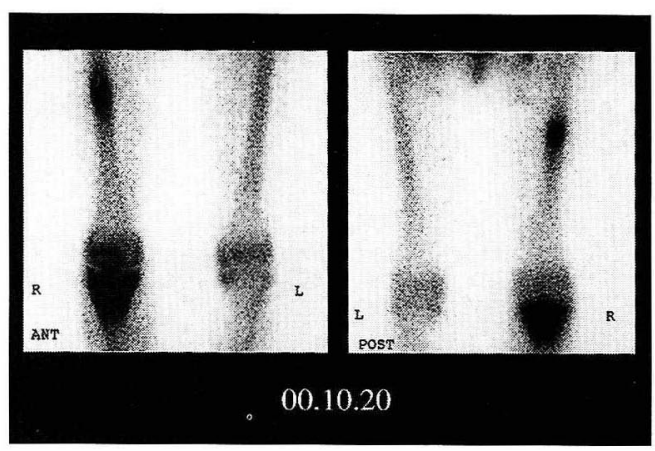

図 7.骨シンチグラフィ 右大腿骨と右脛骨に異常集積部位がみられる 
法を行った。一般に癌の骨転移に対する放射線 治療の適応と目的には(1)疼痛の存在に対する除 痛，(2)四肢などの病的骨折の危険に対する再化 骨化，(3)脊椎に転移した場合の脊椎圧迫に対す る麻痺改善等の圧迫症状の緩和があげられる。 このうち最も適応となる機会が多いのは, 疼痛 の存在である ${ }^{4)}$ 。

治療開始前にはその適応に対し，十分な評価 が不可欠である。症状の責任病巣を明確にする ために MRI や CT が有効であり，これらは骨外 への腫瘍浸潤を確認でき，照射野の設定におい ても必要である ${ }^{5)}$ 。また全身の検索には骨シン チグラフィが有用であり，無症状の病変を発見 することも多い6 ${ }^{6)}$

治療に用いられる放射線は直線加速器 (linear accelerator) で発生するX線が主体であ るが6), 肋骨転移の場合, 肺への照射線量を考慮 し電子線が使用されることもある(1)6)。放射線 線量は短期間に除痛効果を得るために 1 回線量 を3Gy 程度とし，30Gy/ 10 回 / 2 週が一般的 である ${ }^{6) ~ 8) 。 T o n g ~} 5^{81}$ は単発転移に対して $20 \mathrm{~Gy} / 5$ 回/ 1 週および40.5Gy/ 15 回/ 3 週, 多 発転移に対して 15Gy/ 5 回 / 1 週, 20Gy/ 5 回 / 1 週, $25 \mathrm{~Gy} / 5$ 回 / 1 週抒よび $30 \mathrm{~Gy} / 10$ 回 / 2 週の種々の治療スケジュールによる除痛効果 を検討した結果，どのスケジュールでも同様の 除痛効果が得られたとしている。一般には生命 予後不良の患者には 1 ～週の短期間照射を選 択すべきだが，比較的生命予後が良いと考えら れる場合には分割数を多くして多めの総線量を 照射する方が再悪化予防の意味でもよいとされ る $^{4) 6)}$ 。

除痛効果は高く，80 90\% で疼痛の消失もし

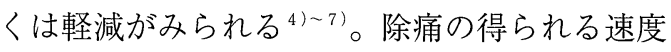
は様々であり，効果の発現する期間は 2 週間以 内に患者の $70 \%$ に, 3 か月以内に患者の $90 \%$ に 除痛効果がみられる ${ }^{4)}$ 。さらに, 除痛の得られた 患者の 55 70\% では，疼痛の再悪化はみられ ず，持続的な効果を示す ${ }^{4)}$ 。自験例では，左寛 骨部に対する除痛効果は放射線治療を開始して
から 1 か月経過してもみられなかったため，硫 酸モルヒネの内服を開始し継続的に使用した。 その後, 右脛骨に照射した頃硫酸モルヒネを中 止することができたが，それより少し以前に左 寛骨に対する除痛効果は現れていた可能性が高 い。

骨転移の除痛効果は腫瘍の組織型と関係なく 得られるとされており ${ }^{910)}$, 茂松ら ${ }^{11)}$ も肺癌と 乳癌という放射線感受性が異なると考えられる 2 つの疾患で，骨転移巣に対する放射線治療の 除痛効果に差異はなかったと報告している。悪 性黒色腫における放射線治療は現時点では皮膚 転移に対して温熱併用療法や速中性子, 熱中性 子が適応となるが，原発巣に対しては著しい効 果を期待できない ${ }^{12)}$ 。しかし，今回の骨転移の 疼痛に対する放射線治療は著効を示し, 原発巣 に感受性があまりない腫瘍でありながら骨転移 巣に対しては除痛効果を認めた。これは，放射 線による骨転移の除痛効果は, 転移部腫瘍の縮 小によって得られるのではなく, 何らかの生化 学的機序が関与しているという説 ${ }^{9) 1314)}$ を支持 するものと考えられる。

このように根治目的ではないにしろ，骨転移 を伴った癌患者に対する放射線療法の除痛効果 は高く, 患者のQOLの向上に及ぼす影響も大き い。また悪性黒色腫という放射線抵抗性である とされている腫瘍に対しても除痛効果を示した ことは，悪性腫瘍の末期医療における治療の選 択肢の 1 つになりうると考えられる。

\section{文献}

1）山本明史：フェロン・DAV 併用療法の基礎と臨 床. Skin Cancer, 6:170-173, 1991 .

2）山崎直也, 山本明史, 和田隆, 他 : Stage IV 悪性 黒色腫に対する Dacarbazine, ACNU, Cisplatin, Tamoxifen 併用化学療法. 日本皮虐科学会雑誌, 109:2123-2128, 1999.

3) Tamm, I., Grimme, H., Brennscheidt, U., et al. : Dacarbazine and interferon alpha for stage IV malignant melanoma. Oncology. 54 :270-274, 1997.

4) 加賀美芳和：骨転移の治療とその痛みに対する効 
果一放射線治療．がん看護，3:174-176, 1998 。

5）鎌田正：がんの骨転移の放射線療法. 整形・災害 外科, 41, 1147-1153, 1996.

6）古川雅彦, 宇木章喜, 井垣浩, 他: 放射線治療と pain control. The Bone, 10:119-124, 1996.

7）荻野尚, 柄川順：癌骨転移の放射線療法. 整形外 科 MOOK, 63:113-123, 1992.

8) Tong, D., Gillick, L., Hendrickson, F.R. : The palliation of symptomatic osseous metastases ; Final result of the study by the radiation therapy oncology group. Cancer, 50:893-899, 1982.

9) Price, p., Hoskin, P.J., Easton, D., et al. : Prospective randomized trial of single and multifraction radiotherapy schedules in the treatment of painful bony matastases. Radiother Oncol, 6:247-255, 1986.
10) Hendrickson, F.R., Shehata, W.M., Kirchner, A.B. : Radiation therapy for osseous metastasis.Int. J. Radiat. Oncol. Biol. Phys., 1 :275-278, 1976.

11）茂松直之，伊東久夫，戸矢和仁，他：有痛性骨転 移に対する放射線治療の鎮痛効果. 日本医学放射 線学会雑誌, 55：677-681, 1995.

12）石原和之：悪性黒色腫の診断と治療一放射線療法 (12). Biotherapy, 11:117-121, 1997.

13) Hoskin, P.J., Price, P., Easton, D., et al. : A prospective randomised trial of $4 \mathrm{~Gy}$ or $8 \mathrm{~Gy}$ single doses in the treatment of metastatic bone pain. Radiother Oncol., 23: 74-78, 1992.

14) Bates, T. : A review of local radiotherapy in the treatment of bone metastases and cord compression. Int. J. Radiat. Oncol. Bio. Phys., 23 : 217-221, 1992. 